\title{
The COVID-19 Pandemic and the Professional Situation on the Real Estate Market in Poland
}

\author{
Maciej KOSZEL
}

Poznań University of Economics and Business, Poznań, Poland, maciej.koszel@ue.poznan.pl

\begin{abstract}
The article deals with the impact of the COVID-19 pandemic on the professional situation of people working on the real estate market in Poland. After the introduction of the pandemic state in Poland, the further restrictions had been implemented and Polish economy, including real estate market deteriorated. In 2019, 468.3 thousand transactions were recorded in Poland - the total value exceeds 121.7 billion PLN and has tripled over the last 10 years. (NBP, 2020) The following research question was formulated: how the professional situation on the real estate market has changed in the 2nd quarter of the 2020 in comparison to the previous period. The main objective of the paper is to identify current and future (expected) professional situation on selected market. For the purposes of the research a survey was conducted among 247 representatives of the professions connected with the real estate market: real estate agents, property managers and property valuators and other. Article describes the detailed research outcomes and focuses on such as aspects as collaboration with clients, operating mode, remote work during pandemic. Due to the specific scope of the studies mainly indigenous, Polish sources were used - Polish National Bank (NBP) and Statistics Poland reports and analysis.
\end{abstract}

Keywords: real estate market; professional situation; coronavirus; pandemic

JEL Classification: I10; R31

\section{Introduction}

The COVID-19 pandemic caused by the SARS-CoV-2 coronavirus (WHO, 2020), which began in the mid November 2019 in the city of Wuhan in central China (Ma, 2020) and had spread dynamically all around the world has contributed to the deterioration of the worldwide economic growth and economic crisis. (NBP, 2020; Nicola et al., 2020; Statistics Poland, 2020; PAP, 2020; The Economist, 2020) The very first case of the coronavirus infection in Poland was confirmed on March 4th, 2020. (Barteczko \& Florkiewicz, 2020; Ministerstwo Zdrowia, 2020) Since then different form of restrictions has been implemented - mostly related with the economic activity of companies and social life of citizens. (Ministerstwo Rodziny, Pracy i Polityki Społecznej, 2020; Ministerstwo Zdrowia, 2020) On the March 20th, 2020 state of pandemic was introduced in Poland (Health Minister, 2020), which has been followed with further difficulties for both companies and citizens, and forced changes and the need to accommodate to the new environment and conditions. Many entrepreneurs decided to limit their economic activity or to start working remotely. (Serwis Rzeczypospolitej Polskiej, 2020) Unfortunately, it was not possible for all the industries and branches of the economy. (Infor Kadry, 2020; Matłacz, 2020; Wróbel, 2020) Similar situation 
could have been observed in other countries as well. (Del Giudice et al., 2020; Hoesli \& Malle, 2020; Tanrivermiş, 2020; Yoruk, 2020)

The real estate market is one of the branches of the economy that is acutely affected by the COVID-19 pandemic. (Dobrowolski, 2020; Musiał \& Boroń, 2020; Nosal, 2020; Otto, 2020; PFRN, 2020; PFSRM, 2020; Zhao, 2020) Ongoing public debate and lack of clear conclusions (Business Insider, 2020; Gazeta Next, 2020; Głowacki, 2020; Interia Biznes, 2020; Money, 2020; PFRN, 2020) has contributed to the decision to prepare research connected with the functioning of the professionals on the real estate market. So called "new economic reality" (Serwis Rzeczypospolitej Polskiej, 2020) has created previously unknown conditions for real estate entrepreneurs and companies. (PFRN, 2020) It was decided to form the following research questions: 1 ) what is the current situation of professionals working on the real estate market, 2) what is the current characteristics of the real estate market in general, 3) what are the future perspectives for the real estate professionals and the market itself?

Due to the wide scope of the presented problem, it was decided to focus on the professional situation of people working in the real estate market only. That is because they are the first to be exposed to the negative outcomes of the ongoing changes, including restrictions related to the professional work. The aim of the article is to evaluate the current and future professional situation of people who work in the real estate market. Due to the practical aspect of the research, the article emphasizes on presenting the empirical results.

\section{Methodology}

The main research was conducted in the April, 2020. Qualitative and quantitative data was collected anonymously and voluntarily. The target group were representatives of professions on the real estate market. The survey was targeted at potential respondents through direct channels and through professional organizations. According to the official data set, the current number of property valuators in Poland is 7,694, the total number of real estate agents is 5,029 and property managers - 2,136. (Ministerstwo Rozwoju, 2020; PFRN, 2020; PFSRM, 2020) It is estimated, that only half of the property valuators are professionally active, and not all of the real estate agents and property managers are registered in the regional associations. This problem is a consequence of the deregulation of the status of real estate agents and property managers in Poland. (AMRON, 2014) 247 correctly completed surveys were received, and it means that the hypothetical percentage return of questionnaires is $1.643 \%$. However, taking into consideration earlier doubts concerning the number of active professionals, the real percentage of return might be significantly higher in this case.

The study used the indirect survey measurement method - an online survey and an electronic survey questionnaire as a measurement tool. (Patton, 1990) The questionnaire was developed using a generally available, free tool. The survey questionnaire was divided into four blocks of questions, i.e.:

1. Demographics (respondent's particulars),

2. The business profile, 
3. The impact of the coronavirus pandemic on the current situation on the real estate market in Poland (March-April 2020),

4. The impact of the coronavirus pandemic on the future situation on the real estate market in Poland (next 12 months).

The third and fourth question blocks were additionally divided into sections, within which the following sections were distinguished:

1. The general situation on the real estate market,

2. The professional situation on the real estate market,

3. The situation in individual segments of the real estate market.

The choice of the scale and variants of the answers depends on the specificity of the question. Most of the detailed questions (block three and four) used a five- and six-point scale of answers (the six-point scale included the "not applicable" option). For the purposes of the article, the results obtained in the section demographics, business profile and the professional situation (present and future) on the real estate market will be discussed.

\section{Results}

\subsection{Respondents Characteristics - Demographics and Business Profile}

This chapter presents the basic demographics and business profile of respondents. The main objective of this chapter is to characterize the respondents. The total of 247 respondents took part in the survey. Figures $1-9$ shows the structure of the respondents according to the following criteria:

- Sex and age (Figure 1),

- Position held in the company (Figure 2),

- Voivodeship, which represents the regions in Poland (Figure 3),

- Size of the population of the city in which the respondent operates (Figure 4),

- Geographical scope of professional activity (Figure 5),

- Type of business (specialty) and market type (Figure 6),

- Held professional licenses or certificates (Figure 7),

- Experience in years (Figure 8),

- Financial situation in the last three years (Figure 9).

The structure of the respondents by gender is balanced, with a slight advantage of women (51\%) over men (49\%) - Figure 1 (left diagram). The respondents were dominated by people between 30 and 39 years of age (42.1\%), the next group are people under the age of 30 (26\%), and the third group in terms of the number of people is "40-year-olds" (20\%) - Figure 1 (right diagram). The vast majority of the respondents have higher education $(96.4 \%)$. 

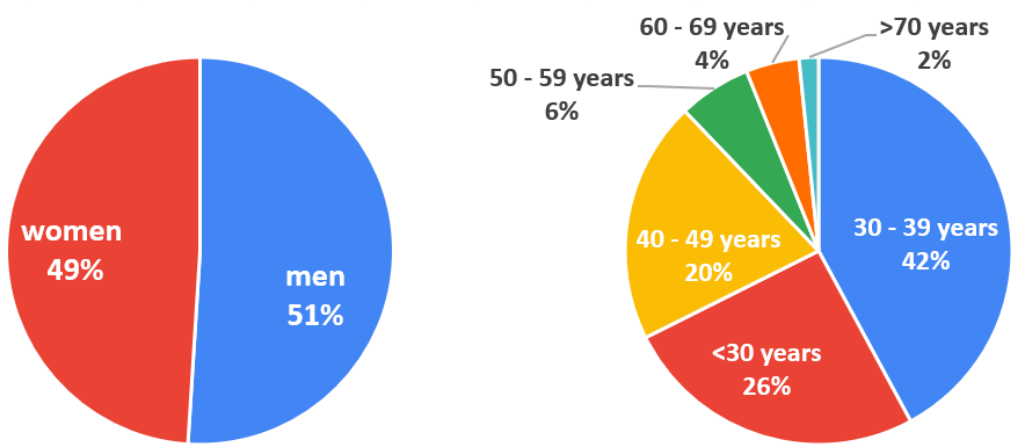

Figure 1. Structure of the respondents by sex (left diagram) and by age (right diagram)

The largest group among the respondents are people who indicated the "owner" as their company position $(46 \%)$, then people holding the position of a specialist $(21 \%)$, then a manager (12\%) and a senior specialist (9\%) - Figure 2.

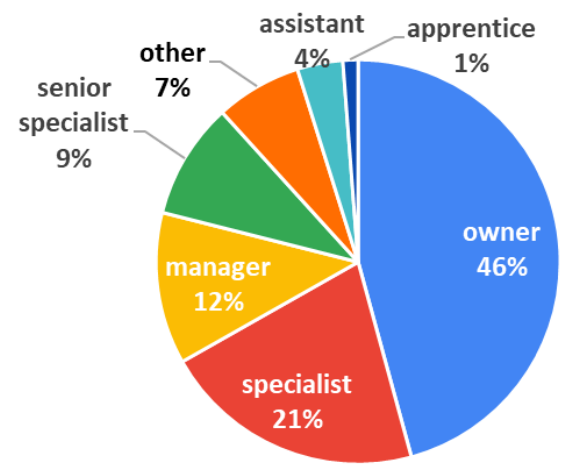

Figure 2. Structure of the respondents by position held in the company

The largest percentage of respondents conducts business / works in the Greater Poland Voivodeship (36\%), Mazowieckie Voivodeship (17\%) and Łódzkie Voivodeship (9\%). The least represented in the survey are the Świętokrzyskie and Warmińsko-Mazurskie Voivodships (one respondent each). There were no representatives of the Podlaskie Voivodeship among the respondents - Figure 3.

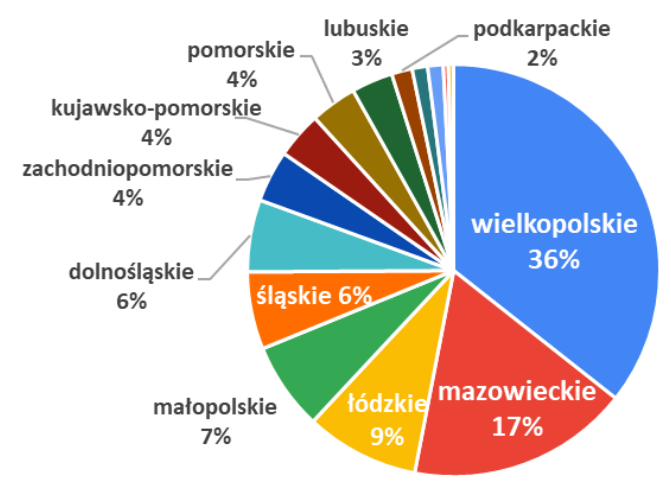

Figure 3. Structure of the respondents by voivodeship.

Nearly half of the respondents $(48.6 \%)$ conduct their business in the largest cities in terms of population (over 500,000 inhabitants), $24.3 \%$ of the respondents work in very large cities (100,000-500,000 inhabitants), while $10.5 \%$ in cities between 50,000-100,000 residents - 
Figure 4. This reflects the spatial distribution of real estate transactions (Statistics Poland, 2020) - the vast majority of which are concluded in the largest Polish agglomerations.

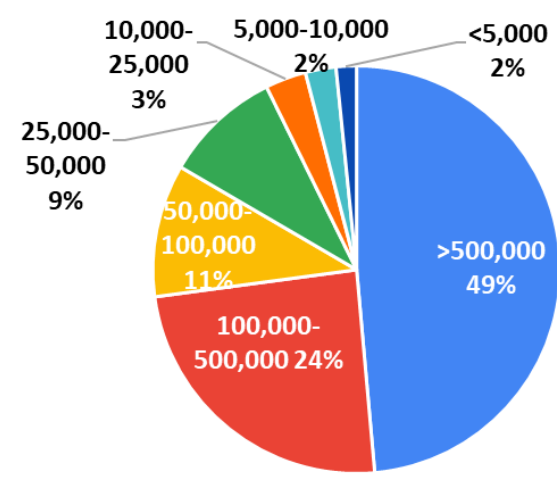

Figure 4. Structure of the respondents according to the size of the population of the city in which they operate.

According to the survey results the largest percentage of the respondents conducts business activities / works in enterprises with a national range of influence (34\%), followed by regional or voivodeship (32\%) and local or poviat (15\%) geographical range. It should be noted that in the case of the largest cities, the poviat self-government is the same as the town / commune (urban poviats). Detailed results concerning the geographical range of business activity are presented in Figure 5.

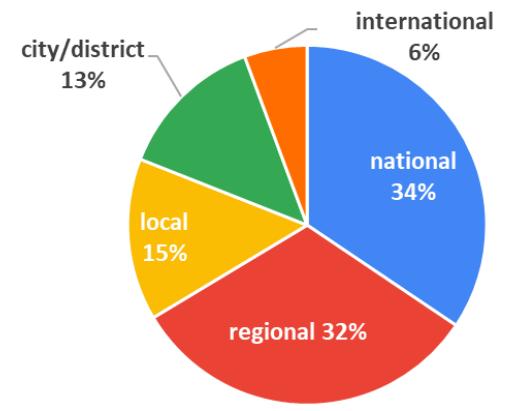

Figure 5. Structure of the respondents according to the geographical scope of professional activity

The largest number of respondents is involved in property valuation (72 respondents; $29 \%$ ), real estate brokerage (65 respondents; $26 \%$ ), property management and investing in the real estate market (50 respondents each; 20\%). A significant proportion of the respondents conduct business activities in which they deal with more than one specialty - 135 people (55\%). A detailed distribution of responses is shown in Figure 6 (left diagram). The vast majority of respondents conduct business / work serving the residential segment of the real estate market (199 respondents, $81 \%$ ). This is the dominant profile of professional activity among most real estate agents, property valuators and property managers, and the largest segment in terms of volume and value of turnover. (Statistics Poland, 2020) Residential market is also the most essential due to the fact that 1) an apartment is a product that satisfies numerous needs and performs various functions (Twardoch, 2019; Górska, 2017), 2) an apartment is a product on the real estate market important from a socio-economic perspective (Centrum AMRON, 2019; Ministry of Development, 2020). 77 respondents (31\%) deal with land trading, 64 respondents (26\%) with the commercial market, and 50 respondents $(20 \%)$ 
with the office market. As in the previous case, a significant part of the survey participants serve more than one segment of the real estate market - 178 respondents $(72 \%)$. The most frequently combined activity is providing services on the residential market and the land trading, which concerns 37 respondents (15\%). The number of respondents who deal only with the residential market stands for 23\% (56 people) of all surveyed. Figure 6 (right diagram) shows the results for each segment (isolated responses).

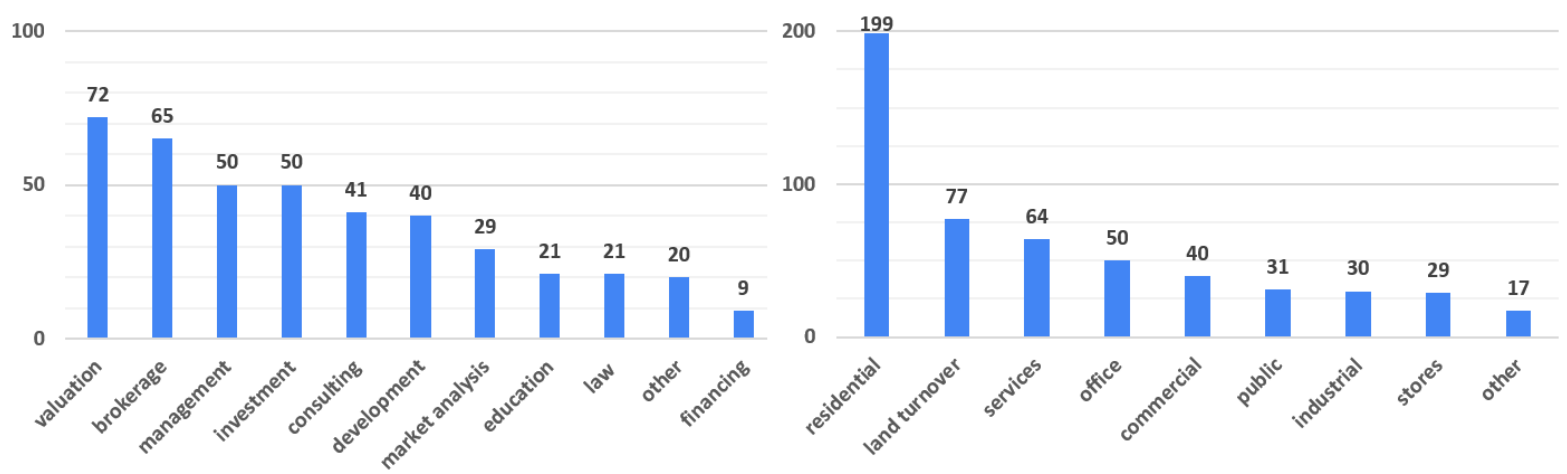

Figure 6. Number of respondents by type of business (specialty) (left diagram) and the real estate market type (right diagram)

The respondents were also asked to indicate their licenses and professional certificates. The amendment to The Property Management Act, which entered into force on January 1st, 2014, deregulated the professions of real estate agent and real estate manager. The role of entities granting professional licenses has been taken over by regional organizations. 39\% of all respondents do not have a license / professional certificate. They are mainly people operating on the residential market. $27 \%$ of all respondents have professional qualifications in the field of property valuation, $18 \%$ a professional license of a real estate agent, and $13 \%$ of a property manager - Figure 7 . On the basis of the obtained answers, it can also be stated that:

- $93 \%$ of the respondents operating as property valuator own a professional license,

- $69 \%$ of respondents operating as real estate agents own a professional license,

- $44 \%$ of respondents operating as real estate manager own a professional license.

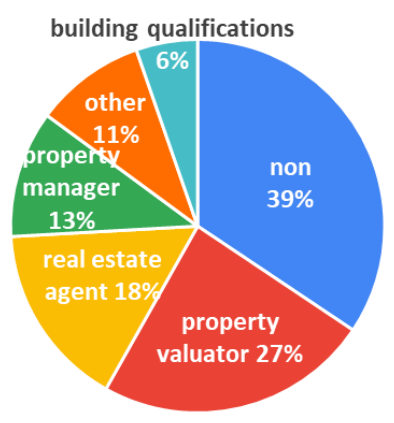

Figure 7. Respondents by held professional licenses / certificates

In the following question, the respondents indicated their professional experience expressed in the number of years of running a business or work related to the real estate 
market. The largest number of respondents (79 respondents; 32\%) indicates experience between 6 and 10 years, then experience up to 5 years (76 respondents; 31\%) and between 11 and 15 years (42 respondents; 17\%) - Figure 8 (left diagram). Assuming that the previous crisis on the real estate market covered the years 2008-2011, it can be assumed that a total of $38 \%$ of the respondents were already working in the real estate profession at that time and can make a comparison between the then and the current situation (causes, course, effects).

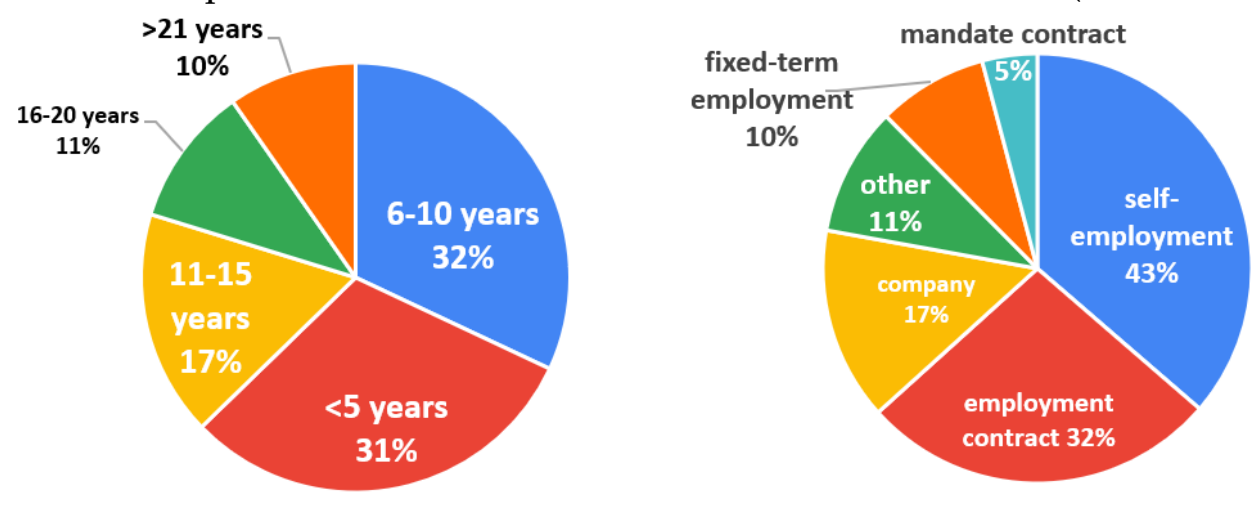

Figure 8. Respondents by their experience in years (left diagram) and by the form of employment (right diagram)

The respondents were also asked to define their current form of employment (professional status). In the question discussed, the respondents could indicate more than one answer variant. The highest percentage of respondents indicates that they are running a sole proprietorship (43\%), followed by an employment contract for an indefinite period (32\%) and running a company employing employees (17\%) - Figure 8 (right diagram). It should be emphasized that some of the professions related to the real estate market can be treated as freelancer profession (property valuator, architect).

In the last question the respondents were asked to define their professional situation in the proceeded three years (before the pandemic), taking into account changes in this area: improvement or deterioration of the professional situation. $40 \%$ of the respondents indicated an improvement in their professional situation, while $28 \%$ indicated a significant improvement in this situation - Figure 9. Therefore, the vast majority of them felt the positive effects of the economic situation on the real estate market in recent years. $30 \%$ of the respondents indicated that the professional situation was maintained, and only $2 \%$ (in total) of respondents declared a deterioration or significant deterioration of the professional situation in the last three years.

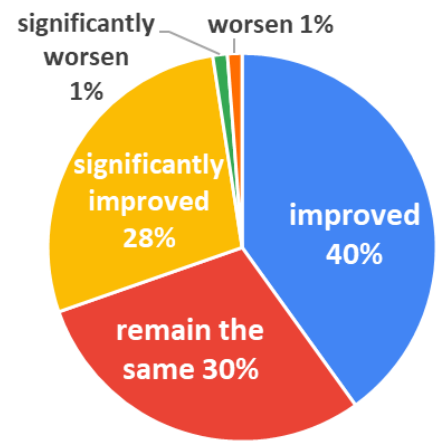

Figure 9. The financial situation of the respondents in the last three years 
To sum up this part of the obtained results it can be stated that:

- The study was attended by representatives of major professional groups dealing with real estate services,

- Most of the respondents operate in very large cities (over 500,000 inhabitants) and large cities (100,000-500,000 inhabitants), which reflects the specificity of the real estate market in Poland and the concentration of potential in the largest cities and their agglomerations,

- The spatial differentiation of the results obtained (in terms of voivodeships) is disturbed - a greater percentage of respondents from Greater Poland Voivodeship and Mazowieckie Voivodeship.

\subsection{Professional Dituation - Results}

The second and the main section of the questions included issues related to the assessment of the current professional situation as compared to the pre-pandemic. Detailed questions concerned:

- Revenues,

- Number of face-to-face meetings with clients,

- Number of contracts signed / concluded transactions,

- Number of phone calls made,

- Number of on-line conversations (chat, videoconferences),

- General interest in real estate on the part of clients,

- Time devoted to professional work (total),

- Time spent working remotely,

- Efficiency as a ratio of the number of concluded contracts to the finalized ones.

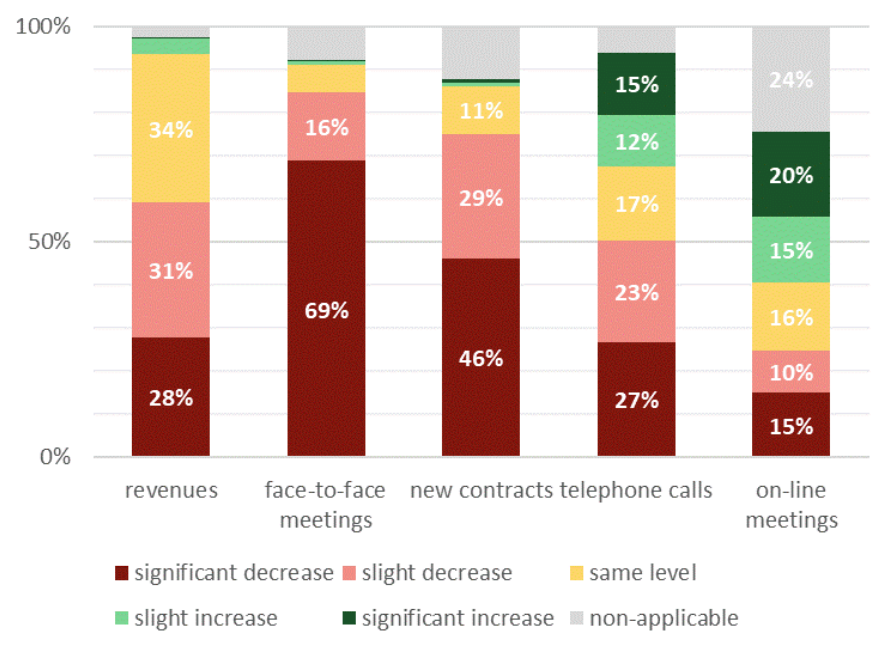

Figure 10. Assessment of the impact of the COVID-19 pandemic on the current professional situation in selected aspects

The overall professional situation of respondents over the last two months (March and April) had significantly worsened - Figure 10. Revenue in 59\% of cases activity / professional work decreased, in 34\% they remained at the same level $85 \%$ of respondents struggle with the problem of a decrease in face-to-face meetings with clients, which also contributes to a 
much smaller number of new contracts signed - Figure 10. The above-mentioned problems mostly concern real estate agents (nearly $90 \%$ of respondents), property valuators (every second respondent) and representatives of real estate developers who provide services to the residential market (based on the answers given in the "business profile" block). The number of telephone calls, which are often the first form of contact, also decreased significantly. This mainly concerns the profession of a real estate agents, sales specialists in development companies, and property valuators serving the residential segment. Remote work and the number of on-line meetings (chat, videoconferences) mainly concern those professions in which direct meetings with clients are not required (analysts, managers, educational and training activities, investing in the real estate market and development activities). However, not all formalities and activities can be carried out using a remote form of work, which can only be used in selected cases.

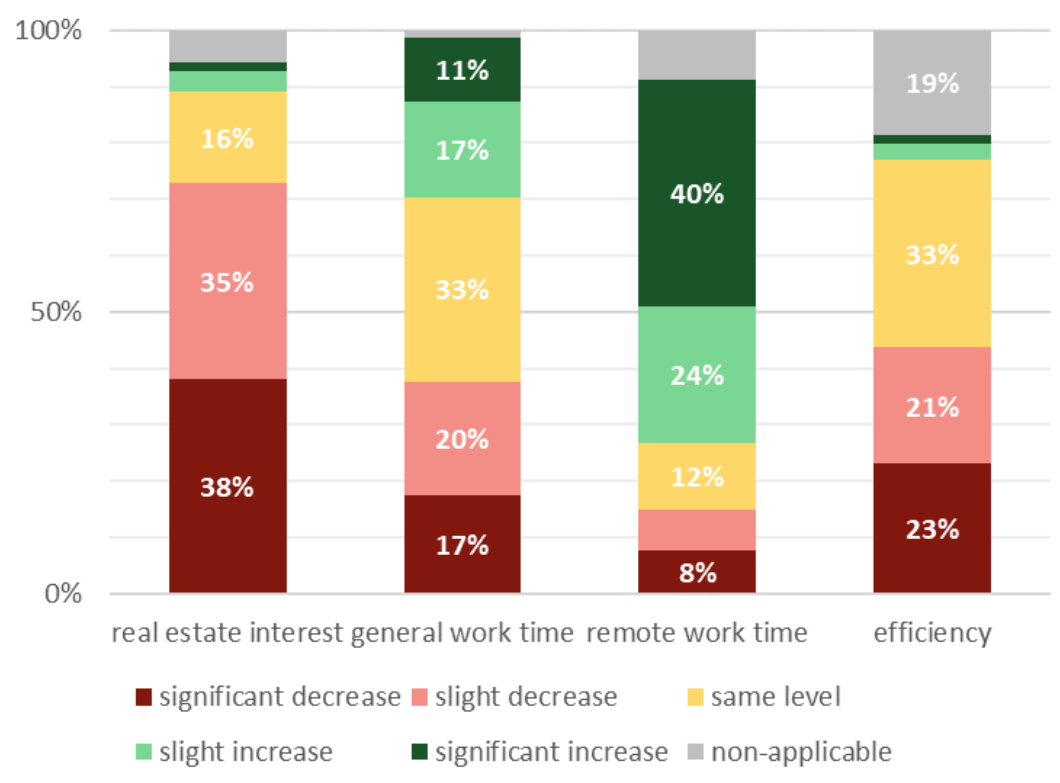

Figure 11. Assessment of the impact of the COVID-19 pandemic on the current professional situation in selected aspects.

$73 \%$ of respondents indicate a decline in the general interest in real estate on the part of clients / buyers / contractors (depending on the profile of activity) - Figure 11 . Only $28 \%$ of respondents indicate an increase in overall working time, every third respondent declares the same working time, while $37 \%$ of respondents experience a slight or significant decrease in this aspect - Figure 11. The most affected group are the respondents, who base their professional work on direct contact with their clients. Two-thirds of respondents indicate an increase in working time remotely, which reflects the general trend and response to the current realities of business and operations. Again, the profile of activity turns out to be key in this case - the greatest increase in remote work concerns people who can work in the socalled back office mode (back office, work that does not require direct contact). The last aspect of the assessment of the current professional situation is related to effectiveness, as a relation of succeeded to the concluded contracts. $44 \%$ of the respondents indicate a decrease, while in every third case the effectiveness remains at the same level. 
The next section of questions was related to the assessment of the future (expected) of the professional situation. The layout of the questions used is the same as in the assessment of the present situation - the same elements as before.

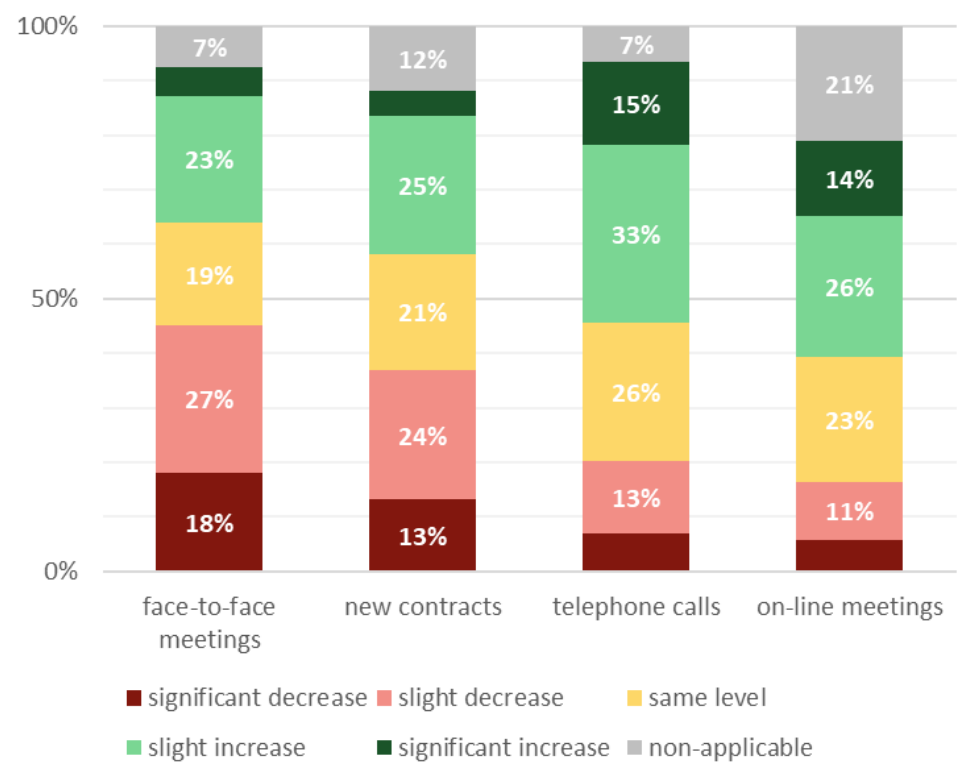

Figure 12. Assessment of the future professional situation in selected aspects

The respondents remain skeptical about their future professional situation - Figure 12. This again mainly applies to those respondents whose professional activity is based on direct contact and meetings with clients / contractors. Negative opinion (decreases and deterioration of the situation) prevails in terms of both expected meetings with clients and new signed contracts, even despite the expected increase in total working time, increase in remote work and improved interest in real estate as the subject of potential transactions.

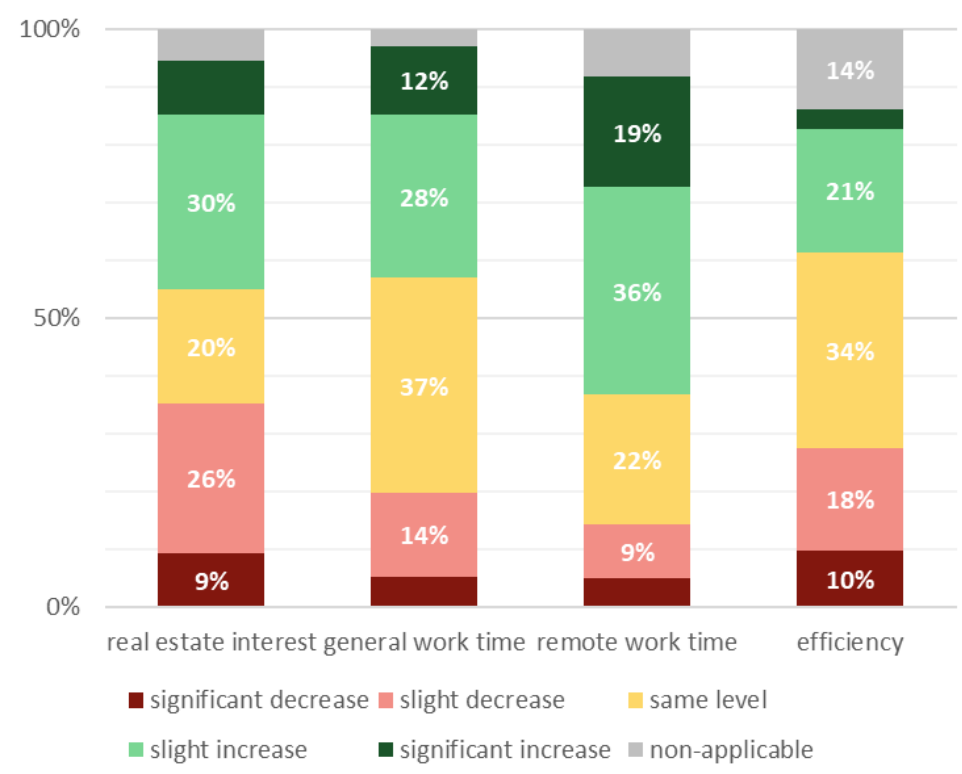

Figure 13. Assessment of the future professional situation in selected aspects

The role of remote work as a form of work, which will become more and more important, was assessed quite unanimously, even among those respondents who have not yet observed 
(March and April) significant increases in this respect - Figure 13. This may prove, on the one hand, the limited possibilities of use in the present conditions and the need to adapt to the new approach, and on the other hand, the different pace of introducing changes among the respondents.

\section{Discussion}

The analysis of the results in terms of the current state of the real estate market gives a picture of a situation that has dramatically worsened in a very short time compared to the last few years, corresponding to the increase in the business cycle - Figures 10-13. This applies in particular to those surveyed who deal with real estate brokerage, sale of real estate (sales specialists in development companies), investing in the real estate market and real estate valuation in the residential segment. This contributes to an unequivocal and extremely negative assessment of the current general and professional situation in the real estate market. The common feature of the indicated groups is the work model based on direct contact with clients or contractors. The use of remote work in this case is possible only to a limited extent, which also does not give positive prospects.

The upcoming months on the real estate market, in the opinion of the respondents, despite many doubts and general uncertainty, are also assessed in a quite skeptical way. This applies both to the assessment of general market development prospects, the professional situation of the respondents and the situation in individual market segments. In terms of the parameters of key importance for the assessment of the future economic situation, the respondents expect further declines and deterioration of the situation.

\section{Conclusions}

To sum up the obtained results, it should be emphasized that the approach and tool used in the study were aimed at verifying the opinion expressed by people professionally involved in the real estate market. Assessments regarding the current situation are declarative, while the assessment of the future situation is the subjective opinion of the respondents.

The conducted research is a contribution to a further, in-depth analysis of changes taking place on the real estate market. The qualitative research on the condition of the market in question "here and now" will have to be supported by the verification of quantitative data, which is systematically collected, processed, analyzed and made public (e.g. by: national statistical offices, central banks or other national or commercial agencies and entities that deal with the real estate market and related industries and branches) (Deloitte, 2020; EY, 2020; JLL, 2020, KPMG, 2020). This approach will give a more complete and reliable picture of the state and the prospects of the real estate market - one of the most complex systems of the national economy. There is also a huge potential for further scientific exploration in identifying specific situation in each type of real estate market in different countries and comparing them showing the similarities and differences - cross comparison among economies and comparative analysis with previous crises. (Franckie \& Korevaar, 2020) 


\section{References}

AMRON. (2014, March 10). Deregulacja zawodu pośrednika w obrocie nieruchomościami i zarzadcy nieruchomości. https://www.amron.pl/aktualnosc.php?tytul=deregulacja-zawodu-posrednika-w-obrocienieruchomosciami-i-zarzadcy-nieruchomosci

Barteczko, A., \& Florkiewicz, P. (2020, March 4). Poland reports first coronavirus case - health minister. Reuters. https://www.reuters.com/article/us-health-coronavirus-poland/poland-reports-first-coronavirus-casehealth-minister-idUSKBN20R0U7

Business Insider. (2020, April 18). Sa tacy, którzy już poluja na okazje na rynku mieszkaniowym. https://businessinsider.com.pl/finanse/inwestowanie/epidemia-koronawirusa-a-rynek-nieruchomosci-wpolsce/1zh1pkw

Deloitte. (2020, March 25). Understanding the sector impact of COVID-19. Real estate. https://www2.deloitte.com/content/dam/Deloitte/global/Documents/About-Deloitte/COVID-19/Covid-19Global-Impacts-on-Real-estate-sector.pdf

Del Giudice, V., De Paola, P., \& Del Giudice, F. P. (2020). COVID-19 Infects Real Estate Markets: Short and MidRun Effects on Housing Prices in Campania Region (Italy). Social Sciences, 9(7), 114. https://doi.org/10.3390/socsci9070114

Dobrowolski, P. (2020, March 19). Najem w czasach pandemii... Polska Federacja Rynku Nieruchomości. https://rejestr.pfrn.pl/porada,351,najem-w-czasach-pandemii

Dziennik Gazeta Prawna. (2020, April 20). NBP tagodzi skutki pandemii i utrzymuje stabilność polskiego pieniądza. (2020, 20 kwietnia). https://gospodarka.dziennik.pl/news/artykuly/7386124,nbp-lagodzi-skutki-pandemii-iutrzymuje-stabilnosc-polskiego-pieniadza.html

EY. (2020, October 5). COVID-19. Indutry Pulse Report: Real Estate. https://www.ey.com/en_cy/covid-19updates/pulse-report-realestate

Franckie, M., \& Korevaar, M. (2021). Housing Markets in a Pandemic: Evidence from Historical Outbreaks. SSRN Electronic Journal, 1-54. https://doi.org/10.2139/ssrn.3566909

Gazeta Next. (2020, May 7). Jak bardzo koronawirus uderza w rynek nieruchomości? "Sprzedaż zmalała, ale nie aż tak mocno". $\quad$ https://next.gazeta.pl/next/7,151003,25923876,jak-bardzo-koronawirus-uderza-w-ryneknieruchomosci-sprzedaz.html

Głowacki, J. (2020, March 4). Koronawirus a rynek nieruchomości. Puls Biznesu. https://www.pb.pl/koronawirus-arynek-nieruchomosci-984156

Hoesli, M. E. R., \& Malle, R. (2021). Commercial Real Estate Prices and Covid-19. Swiss Finance Institute Research Paper, 21-28. http://dx.doi.org/10.2139/ssrn.3773532

Infor Kadry. (2020, March 23). Praca zdalna podczas epidemii koronawirusa a dyskryminacja w zatrudnieniu. https://kadry.infor.pl/kadry/indywidualne_prawo_pracy/odpowiedzialnosc_prawa_i_obowiazki/3632832,3 ,Praca-zdalna-podczas-epidemii-koronawirusa-a-dyskryminacja-w-zatrudnieniu.html

Interia Biznes. (2020, May 2). Koronawirus odmienia rynek nieruchomości. https://biznes.interia.pl/nieruchomosci/news-koronawirus-odmienia-ryneknieruchomosci,nId,4465736\#utm_source=paste\&utm_medium=paste\&utm_campaign=firefox

JLL. (2020, March 12). COVID-19. Global Real Estate Implications. https://www.jll.pl/pl/trendy-ianalizy/badanie/covid-19-global-real-estate-implications

KPMG. (2020). The implications of COVID-19 for the real estate industry. https://assets.kpmg/content/dam/kpmg/im/pdf/COVID-19-and-Real-Estate-Impact-IOM.pdf

Ma, J. (2020, March 13). Coronavirus: China's first confirmed Covid-19 case traced back to November 17. https://www.scmp.com/news/china/society/article/3074991/coronavirus-chinas-first-confirmed-covid-19case-traced-back

Matłacz, A. (2020, March 29). Po koronawirusie praca z domu może zyskać na popularności. Prawo Kadry. https://www.prawo.pl/kadry/czy-koronawirus-zmieni-na-stale-podejscie-pracodawcow-dopracy, 499057.html

Ministerstwo Rodziny, Pracy i Polityki Społecznej. (2020, March 13). Pracownik i przedsiębiorca w obliczu koronawirusa - praktyczny poradnik. https://www.gov.pl/web/rodzina/pracownik-i-przedsiebiorca-w-obliczukoronawirusa---praktyczny-poradnik

Ministerstwo Rozwoju. (2020). Centralny Rejestr Rzeczoznawców Majątkowych [Data set]. Retrieved May 5, 2020 from https://www.gov.pl/web/rozwoj/centralny-rejestr-rzeczoznawcow-majatkowych

Ministerstwo Zdrowia. (2020). COVID - informacje. https://www.gov.pl/web/zdrowie/covid 
Ministerstwo Zdrowia. (2020, March 4). Pierwszy przypadek koronawirusa w Polsce. https://www.gov.pl/web/zdrowie/pierwszy-przypadek-koronawirusa-w-polsce

Money. (2020, May 10). Czy koronawirus zaraził rynek nieruchomości? https://www.money.pl/gospodarka/czykoronawirus-zarazil-rynek-nieruchomosci-6508646776313985a.html

Musiał, M., \& Boroń, M. (2020, March 4). Glapiński: panika zwiazana z koronawirusem niesie ryzyko osłabienia koniunktury. https://www.pap.pl/aktualnosci/news,598687,glapinski-panika-zwiazana-z-koronawirusemniesie-ryzyko-oslabienia

NBP. Narodowy Bank Polski. (2020, March 13).Wypowiedź Prezesa NBP, Prof. Adama Glapińskiego dla Polskiej Agencji Prasowej. https://www.nbp.pl/home.aspx?f=/aktualnosci/wiadomosci_2020/Prezes-NBP-dla-PAP.html

NBP. Narodowy Bank Polski. (2020, March 16). Komunikat Komitetu Stabilności Finansowej po posiedzeniu dotyczacym nadzoru makroostrożnościowego nad systemem finansowym https://www.nbp.pl/nadzormakroostroznosciowy/komunikaty/2020-03-16.aspx

Nicola, M., Alsafi, Z., Sohrabi, C., Kerwan, A., Al.-Jabir, A., Iosifidis, C., Agha, M., \& Agha, R. (2020). The socioeconomic implications of the coronavirus pandemic (COVID-19): A review. International Journal of Surgery, 78, 185-193. https://doi.org/10.1016/j.ijsu.2020.04.018

Nosal, B. (2020, March 21). Jak koronawirus wpłynie na ceny mieszkań w Polsce? Ekspert: Nie ma paniki, oby nie było katastrofy. Gazeta Wyborcza. https://poznan.wyborcza.pl/poznan/7,36001,25808965,jak-koronawiruswplynie-na-ceny-mieszkan-w-polsce-ekspert.html

Otto, P. (2020, April 29). Deweloperzy będą rolować obligacje. Dziennik Gazeta Prawna. https://serwisy.gazetaprawna.pl/nieruchomosci/artykuly/1473142,koronawirus-a-rynek-deweloperskirolowanie-obligacji.html

PAP. Polska Agencja Prasowa. (2020, March 13). Glapiński: będę proponowat Radzie Polityki Pieniężnej obniżenie stóp procentowych NBP. https://www.pap.pl/aktualnosci/news,605075,glapinski-bede-proponowal-radziepolityki-pienieznej-obnizenie-stop

Patton, M. Q. (1990). Qualitative evaluation and research methods (2nd ed.). Sage Publications, Inc.

PFRN. Polska Federacja Rynku Nieruchomości. (2020). Centralny Rejestr Pośredników w Obrocie Nieruchomościami PFRN. [Data set]. Retrieved May 9, 2020 from https://rejestr.pfrn.pl/posrednicy

PFRN. Polska Federacja Stowarzyszeń Rzeczoznawców Majątkowych. (2020). Członkowie PFSRM. [Data set]. Retrieved May 9, 2020 from http://www.pfsrm.pl/czlonkowie

PFRN. Polska Federacja Rynku Nieruchomości. (2020). Centralny Rejestr Zarządców Nieruchomości. [Data set]. Retrieved May 9, 2020 from https://rejestr.pfrn.pl/zarzadcy

PFRN. Polska Federacja Rynku Nieruchomości. (2020). Lista stowarzyszeń. [Data set] Retrieved May 9, 2020 from https://rejestr.pfrn.pl/stowarzyszenia

PFSRM. Polska Federacja Stowarzyszeń Rzeczoznawców Majątkowych. (2020, March 25). Komunikat TEGoVA w sprawie wyceny $w$ czasie pandemii. https://pfsrm.pl/aktualnosci/item/585-komunikat-tegova-w-sprawiewyceny-w-czasie-pandemii

PFSRM. Polska Federacja Stowarzyszeń Rzeczoznawców Majątkowych. (2020, April 1). Nowe ograniczenia w zwiazku z wystapieniem stanu epidemii. https://pfsrm.pl/aktualnosci/item/588-nowe-ograniczenia-w-zwiazkuz-wystapieniem-stanu-epidemii

PFSRM. Polska Federacja Stowarzyszeń Rzeczoznawców Majątkowych. (2020, March 25). Nowe zasady bezpieczeństwa w zwiazku $z$ koronawirusem. https://pfsrm.pl/aktualnosci/item/586-nowe-zasadybezpieczenstwa-w-zwiazku-z-koronawirusem

PFSRM. Polska Federacja Stowarzyszeń Rzeczoznawców Majątkowych. (2020, April 17). Rekomendacje dla rzeczoznawców majątkowych dotyczace wykonywania czynności zawodowych w okresie pandemii koronawirusa. https://pfsrm.pl/aktualnosci/item/594-rekomendacje-dla-rzeczoznawcow-majatkowych-dotyczacewykonywania-czynnosci-zawodowych-w-okresie-pandemii-koronawirusa

Regulation no. 2020/491, The declaration of an epidemic state in Poland. Health Minister. Republic of Poland. https://isap.sejm.gov.pl/isap.nsf/download.xsp/WDU20200000491/O/D20200491.pdf

Serwis Rzeczypospolitej Polskiej. (2020, April 16). W ramach nowej rzeczywistości gospodarczej proponujemy dzisiaj nowe zasady. https://www.premier.gov.pl/wydarzenia/aktualnosci/premier-w-ramach-nowejrzeczywistosci-gospodarczej-proponujemy-dzisiaj-nowe.html

Serwis Rzeczypospolitej Polskiej. (2020, May 11). Prawa $i$ obowiazki pracownika podczas epidemii. https://www.gov.pl/web/koronawirus/prawa-i-obowiazki-pracownika-podczas-epidemii 
Statistics Poland. (2020). Real estate sales in 2019. Statistics Poland, Trade and Services Department. https://stat.gov.pl/obszary-tematyczne/infrastruktura-komunalna-nieruchomosci/nieruchomosci-budynkiinfrastruktura-komunalna/obrot-nieruchomosciami-w-2019-roku,4,17.html

Statistic Poland. (2020). Szybki szacunek produktu krajowego brutto za pierwszy kwartał 2020 roku. Statistics Poland, National Accounts Department. https://stat.gov.pl/obszary-tematyczne/rachunki-narodowe/kwartalnerachunki-narodowe/szybki-szacunek-produktu-krajowego-brutto-za-pierwszy-kwartal-2020roku, 1,29.html

Statistics Poland. (2020). Obroty towarowe handlu zagranicznego ogółem i według krajów w okresie styczeń-marzec 2020 roku. Statistics Poland, Trade and Services Department. https://stat.gov.pl/obszary-tematyczne/cenyhandel/handel/obroty-towarowe-handlu-zagranicznego-ogolem-i-wedlug-krajow-w-okresie-styczenmarzec-2020-roku,1,92.html

Tanrivermiş, H. (2020). Possible impacts of COVID-19 outbreak on real estate sector and possible changes to adopt: A situation analysis and general assessment on Turkish perspective. Journal of Urban Management, 9(3), 263269. https://doi.org/10.1016/j.jum.2020.08.005

The Economist. (2020, April 16). Is China winning? https://www.economist.com/leaders/2020/04/16/is-chinawinning

World Health Organization. (2020). Coronavirus disease (COVID-19) pandemic. https://www.who.int/emergencies/diseases/novel-coronavirus-2019

Wróbel, M. (2020, April 26). Koronawirus: czy praca zdalna zostanie z nami na dobre. Rzeczpospolita. https://www.rp.pl/Kadry/304229972-Koronawirus-czy-praca-zdalna-zostanie-z-nami-na-dobre.html

Yoruk, B. (2020). Early Effects of the COVID-19 Pandemic on Housing Market in the United States, SSRN Electronic Journal, 1-28. http://dx.doi.org/10.2139/ssrn.3607265

Zhao, Y. (2020). US Housing Market during COVID-19: Aggregate and Distributional Evidence. COVID Economics, 50, 113-154. https://doi.org/10.2139/ssrn.3677651 